\title{
Teachers' Training: Impact on Mental Health, Knowledge and Skills
}

\author{
Gina Tomé ${ }^{1 *}$, Paulo Gomes ${ }^{2}$, Inês Camacho ${ }^{3}$, Lucia Ramiro ${ }^{4}$ and Margarida Gaspar de Matos ${ }^{5}$ \\ ${ }^{1} \mathrm{FMH} /$ Universidade de Lisboa, ISAMB/ Universidade de Lisboa, Portugal. \\ ${ }^{2}$ Pressley Ridge Associação. \\ ${ }^{3} \mathrm{FMH} /$ Universidade de Lisboa, ISAMB/Universidade de Lisboa, Portugal. \\ ${ }^{4} \mathrm{FMH} /$ Universidade de Lisboa, ISAMB/Universidade de Lisboa, Portugal \\ ${ }^{5}$ FMH/Universidade de Lisboa, ISAMB/Universidade de Lisboa, APPSYci/ISPA, Lisboa Portugal \\ *Corresponding Author: Gina Tomé, FMH/Universidade de Lisboa, ISAMB/ Universidade de Lisboa, Portugal. E-mail: ginatome@ sapo.pt \\ Received Date: September 04, 2020; Accepted Date: September 17, 2020; Published Date; September $22,2020$. \\ Citation: G Tomé, P Gomes, I Camacho, L Ramiro and Margarida GD Matos, (2020). Teachers' Training: Impact on Mental Health, Knowledge \\ and Skills, J. Psychology and Mental Health Care. 4(5). Doi: 10.31579/2637-8892/101
}

Copyright: (C) 2020. Gina Tomé, This is an open-access article distributed under the terms of the Creative Commons Attribution License, which permits unrestricted use, distribution, and reproduction in any medium, provided the original author and source are credited

\begin{abstract}
Teachers have a fundamental role in transforming the school's environment into a context of well-being and in promoting young people's mental health. The main goal of ES'COOL training is to promote adolescents' mental health by empowering teachers and school staff with skills that will enable them to build a balanced school environment. The aim of this study was to analyse the impact that teacher training in the area of mental health had on their skills and knowledge regarding mental health. The sample was constituted by 276 teachers who work in schools in Portuguese mainland and participated in the ES'COOL training. Two evaluation moments were carried out, the initial evaluation - one week before the beginning of the training, and the final evaluation - one week after the end of the training. Results show that teachers improved most of the assessed skills and knowledge after training. Problem-solving, motivation and leadership were the skills that increased the most after the training.
\end{abstract}

Keywords: mental health promotion; teacher training; adolescents' mental health

Running head: Teachers' training impact

\section{Introduction}

One of the important goals of education is that students can express themselves, cope with their emotions and resolve their problems correctly. One of the important goals of education is that students can express themselves, cope with their emotions and resolve their problems correctly. The psychological and emotional well-being of students has become an increasing priority in schools, and recent studies in the area of mental health and adolescents have highlighted the need for a greater emphasis on the area because of the growing incidences of depression, suicide, and anxiety rates among students and the decrease in the average age of onset [1]. According to the World Health Organization, mental health is a "state of well-being in which the individual realizes his or her own abilities, can cope with the normal stress of life, can work productively and fruitfully, and is able to make a contribution to his or her own community" [2].

At this point, it seems that the leadership of teachers is essential. Teachers who have a high level of emotional intelligence and problemsolving skills will make a significant impact on their students' skills. Teachers with these skills can provide a positive psychological environment [3]

Teachers are vital professionals in responding to young people with possible mental health difficulties and who show social, emotional or behavioural problems in the classroom. Health and education policies increasingly position teachers as vital agents in connecting mental health services with affected young people [4]. In their study, found the overriding need for explicit and structured guidance for pre-service educators on how to respond to children or young people who present with possible mental health problems. Conceptually speaking, data disclose the need for clear, but not simplistic, guidance on how common mental health problems are manifested in children and young people. It seems to be of major importance that teachers are encouraged to be alert for warning signs warranting careful consideration or timely action, but strongly discouraged, even informally, to diagnose young people.

[5] Conducted a study with 1029 Australian and Maltese teachers about their skills in what mental health promotion is concerned. They reported that participating teachers generally have positive attitudes towards mental health promotion. However, the responses from teachers illustrated some potential difficulties when translating positive attitudes into actual practices.

[6] Conducted a study to verify which factors at the individual and organizational levels relate to differences upon teachers' reported negative emotions, perceived responsibility, and competence in student mental health promotion. The author reported that teacher stress emerges chiefly from a mismatch between feeling responsible for and being able to help students with mental health problems. The data also point to the impact of time constraints in the school context. Finally, the findings 
reveal significantly higher levels of perceived responsibility and negative emotions amongst female teachers, and significantly lower levels of perceived responsibility amongst teachers at higher grades.

Mental health is one of the many factors alleged to affect academic achievement positively or negatively. The minds, intellectual competences, and social skills of young people are still in the constructive stages of growing up. Thus, to handle young minds successfully and to be able to cope with the expectations of important educational stakeholders, such as parents and the community, a teacher may need to have good mental health and understand the dangerous effects and implications of poor mental health for teaching and learning [7].

Severiens, [8] analysed the curriculum of a teacher training college and found some basic competences that teachers are expected to acquire during their training: interpersonal competence, pedagogical competence, scientific competence, and competence in cooperation with parents and other professionals.

[9] Consider that sensitizing teachers about the mental health needs of school-going children will help them to develop insight into the importance of the promotion of positive mental health as well as the early identification and subsequent management of psychological problems. Conversely, teachers who are unaware of this can have a narrow and stigmatized perception, and over or under pathologies that can delay carrying out any program related to mental health in schools.

\begin{tabular}{|c|c|c|c|c|c|}
\hline 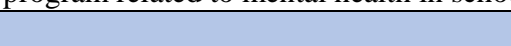 & $N$ & $\%$ & $M$ & $S D$ & Range. \\
\hline \multicolumn{6}{|l|}{ Sample } \\
\hline First cycle teacher & 36 & 13 & & & \\
\hline Teachers (5th to 12th grade) & 173 & 62.7 & & & \\
\hline Kindergarten teachers & 17 & 6.2 & & & \\
\hline Special education teachers & 35 & 12.7 & & & \\
\hline Psychologists and other specialists & 15 & 5.4 & & & \\
\hline \multicolumn{6}{|l|}{ Gender } \\
\hline Male & 32 & 11.6 & & & \\
\hline Female & 244 & 88.4 & & & \\
\hline Age & 276 & - & 47.9 & 7.2 & $27-68$ \\
\hline \multicolumn{6}{|l|}{ Educational Level } \\
\hline Bachelor Degree & 4 & 1.4 & & & \\
\hline Graduate & 201 & 72.8 & & & \\
\hline Master & 55 & 19.9 & & & \\
\hline $\mathrm{PhD}$ & 7 & 2.5 & & & \\
\hline Other & 9 & 3.3 & & & \\
\hline \multicolumn{6}{|l|}{ Professional Situation } \\
\hline Permanent & 192 & 69.6 & & & \\
\hline Temporary & 55 & 19.9 & & & \\
\hline Other & 29 & 10.5 & & & \\
\hline Years of Service & 275 & - & 21.4 & 8 & $0-41$ \\
\hline Years of service in the current school & 276 & - & 8.3 & 8.7 & $0-35$ \\
\hline
\end{tabular}

Table 1 - Demographic Characteristics of the Participants

Eighty-six projects were developed by teachers, with the supervision of the trainers of the project ES'COOL. Of the 86 projects, 26 were related to well-being, 17 with mental health, 9 with behaviors and indiscipline, 8 with the prevention of risk behaviors, 8 related to promoting positive relationships, 7 with personal and social skills, 8 projects related to school skills, 2 with the promotion of the relationship between family and school and 1 related to racial discrimination.

About $17.4 \%$ of the teachers reported that they had already had mental health training.

\section{Measures and variables}

In addition to teachers, the whole school community has an essential role in young mental health promotion. It is strongly recommended to implement school-based intervention programs in the mental health area, with a long-term follow-up, effective monitoring of the quality of its implementation, in line with an adequate training of the intervention team. An effective multi-source evaluation of the intervention should be included, along with family sessions. [10].

This study aimed at analysing the impact of teacher training, in the area of mental health, on teachers' competences and knowledge about mental health.

\section{Method}

\section{Participants}

The sample was constituted by 276 teachers who worked in schools in mainland Portugal and who participated in the ESCOOL training. Of the 276 teachers, $11.6 \%$ are males and $88.4 \%$ females, with an average age of $47.9(S D=7.2$; Min -27; Max- 68) and an average of 21.4 years $(S D=8$; Min- 0 ; Max- 41$)$ of service.

Of the teachers who did the ES'COOL training, $72.8 \%$ were graduates, $19.9 \%$ had a Master's Degree, $2.5 \%$ a Ph.D. and $1.4 \%$ a Bachelor Degree (see table 1). 
The "Scale of Mental Health Knowledge and Attitudes in a School Context - ES'COOL" is a questionnaire consisting of 29 items, whose answers are given according to a 5-point Likert intensity scale. The subject should indicate the degree of agreement or disagreement, in which $1=$ "strongly disagree", 3 = "I do not disagree or agree" and $5=$ "Strongly agree". The analysis of the "Scale of Mental Health Knowledge and Attitudes in a School Context - ES'COOL" was carried out taking into account the Behaviour Change Wheel Model (BCW) [12].

Life satisfaction, professional satisfaction, problems solving, leadership ability, social environment and interpersonal relations in school and skills and knowledge in mental health were evaluated on a scale from 0 to 10 in which 0 represents the worst and 10 the best option.

Happiness was assessed using the self-report Subjective Happiness Scale [13]. The happiness scale is a 4-item subjective happiness scale that measures overall happiness. It is derived from a 7-point Likert scale ranging from 1 to 7 , in which $1=$ not a very happy person and $7=$ a very happy person. A composite score for global subjective happiness is obtained by averaging the responses to all the four items on the subjective happiness scale. The possible score range is from 1 to 7 , higher scores reflecting greater happiness.

The affective dimension was measured via the Positive and Negative Affect Schedule - PANAS [13]. The PANAS is a questionnaire consisting of 20 items, whose answers are given according to a 5-point Likert intensity scale in which, through a series of feelings or emotions, the subject should indicate the degree of agreement or disagreement $(1=$ "very slightly or not at all", 3 = "Moderately" and 5 = "Extremely"). The items are divided into two sub-scales, representing two mood states or two affective dimensions: Positive Affects (PA) and Negative Affects (NA). While PA reflect feelings of enthusiasm, activity, and alertness, i.e. a state of energy, complete concentration and pleasure in the tasks performed (10 items - Example: "Interested"), NA represents a general dimension of aversive feelings (10 items - Example: "Afflicted"). Low values in Positive Affects mean sadness and lethargy, and low values in Negative Affects mean calm and serenity [14].

\section{Procedures}

The main goal of "ES'COOL" is to promote adolescents' mental health through capacity building of school teachers and school staff. The program aims at the development of personal and social skills and includes the prevention of anxiety and depression symptoms, the promotion of resiliency, and self-regulation in adolescents. The ES'COOL training was implemented with teachers from primary and secondary schools (from 1 st to $12^{\text {th }}$ grade), kindergarten and special education teachers covering schools from all the regions of Portugal. There have been training groups all over Portugal, namely in the North, Center, Lisbon, and Algarve regions.

The first assessment of the study was conducted one week before the start of the training, while the second one was carried out two weeks after the ES 'COOL training. Data collection was performed

\begin{tabular}{|c|c|c|c|c|c|c|}
\hline & Factor & Items & $\mathbf{N}$ & $M$ & $S D$ & Cronbach \\
\hline \multirow{4}{*}{$\begin{array}{lr}\text { Mental } & \text { Health } \\
\text { Knowledge } & \text { and } \\
\text { Attitudes } & \end{array}$} & $\begin{array}{l}\text { Emotional } \\
\text { Capability }\end{array}$ & 5 & 268 & 18,5 & 2,8 & .80 \\
\hline & $\begin{array}{ll}\text { Problem } & \text { Solving } \\
\text { Capability } & \\
\end{array}$ & 5 & 268 & 21,1 & 2,2 & .69 \\
\hline & Motivation & 4 & 268 & 17,6 & 1,9 & .72 \\
\hline & Opportunity & 4 & 268 & 14,1 & 2,3 & .70 \\
\hline \multirow{2}{*}{ PANAS } & Positive Affects & 10 & 275 & 35,7 & 5,5 & .89 \\
\hline & Negative Affects & 10 & 275 & 16,1 & 5,2 & .84 \\
\hline \multirow{3}{*}{ Alienation } & Demotivation & 5 & 182 & 11,4 & 2,4 & .69 \\
\hline & Instability & 3 & 182 & 8,7 & 1,6 & .51 \\
\hline & Isolation & 2 & 182 & 4,3 & 1,6 & .76 \\
\hline
\end{tabular}




\begin{tabular}{|l|l|l|l|l|l|l|}
\hline & Happiness & 4 & 274 & 20,9 & 3,6 & .75 \\
\hline & Self-efficacy & 4 & 182 & 15,3 & 2,1 & .78 \\
\hline & Future expectations & 9 & 182 & 33,7 & 4,8 & .77 \\
\hline
\end{tabular}

Table 2 - Internal consistency of the scales

A correlation analysis was conducted between the analysed variables (see table 3). Positive associations were found between the emotional capability variable and: problem solving capability (.558), motivation (.418), opportunity (.303), happiness (.190), positive affects (.239), professional satisfaction (.186), mental health literacy (.432), problem management (.205), leadership ability (.191), future expectations (.177) and self-efficacy (.331) Negative associations were shown between the emotional capability and: demotivation (-.246) and negative affects(.127). Problem solving capability were positively correlated: motivation (.595), opportunity (.247), happiness (.323), positive affects (.322), life satisfaction (.159), professional satisfaction (.257), social environment and interpersonal relations in school (.168), mental health literacy (.191), problem management (.222), leadership ability (.185), future expectations (.285), self-efficacy (.393). On the other hand, problem solving capability were negatively correlated with: demotivation (-.245) and isolation (.215). It was also found positive associations between motivation and: opportunity (.225), positive affects (.145), professional satisfaction (.120), self-efficacy (.226) and negative associations between motivation and: demotivation (-.217) and isolation (-.160). Positive associations between opportunity and: mental health literacy (.134). Positive associations between demotivation and: isolation (.245) and negative associations between demotivation and: happiness (-.319), positive affects (-.334), life satisfaction (-.156), professional satisfaction (-.159), social environment and interpersonal relations in school (-.260), mental health literacy (-.151), problem management (-.381), leadership ability ($.268)$, future expectations (-.373) and self-efficacy (-.379). Positive associations between instability and: isolation (.290), negative affects (.210) and negative associations between instability and: professional satisfaction (-.161), problem management (-.201). Positive associations between isolation and: negative affects (.286) and negative associations between isolation and: happiness (-.277), positive affects (-.225), life satisfaction (-.276), professional satisfaction (-.159), social environment and interpersonal relations in school (-.221), problem management (-
$.341)$, leadership ability (-.222), future expectations (-.251) and selfefficacy (-.251). Positive associations between happiness and: positive affects (.552), life satisfaction (.509), professional satisfaction (.383), social environment and interpersonal relations in school (.311), problem management (.447), leadership ability (.280), future expectation (.389), self-efficacy (.483) and negative associations between happiness and: negative affects (.444). Positive associations between positive affects and: life satisfaction (.307), professional satisfaction (.329), social environment and interpersonal relations in school (.308), mental health literacy (.239), problem management (.433), leadership ability (.324), future expectations (.212), self-efficacy (.411) and negative associations between positive affects and: negative affects (-.219). Negative associations between negative affects and: life satisfaction (-.332), professional satisfaction (-.190), social environment and interpersonal relations in school (-.152), problem management (-.217), future expectations (-.179). Positive associations between life satisfaction and: professional satisfaction (.502), social environment and interpersonal relations in school (.411), mental health literacy (.198), problem management (.453), leadership ability (.302), future expectations (.251) and self-efficacy (.313). Positive associations between professional satisfaction and: social environment and interpersonal relations in school (.427), mental health literacy (.293), problem management (.354), leadership ability (.233), future expectations (.188) and self-efficacy (.202). Positive associations between social environment and interpersonal relations in school and: mental health literacy (.411), problem management (.461), leadership ability (.467) and future expectations (.217). Positive associations between mental health literacy and: problem management (.191) and leadership ability (.358). Positive associations between problem management and leadership ability (.575), future expectations (.308) and self-efficacy (.411). Positive associations between leadership ability and: future expectations (.222) and selfefficacy (.306). And finally, there are positive associations between future expectations and self-efficacy (.399).

\begin{tabular}{|c|c|c|c|c|c|c|c|c|c|c|c|c|c|c|c|c|c|}
\hline & (2) & (3) & (4) & (5) & (6 & (7) & (8) & (9) & (10) & (11 & )$^{(12}$ & (13) & $(14$ & (15) & (16) & (17) & (18) \\
\hline $\begin{array}{l}\text { (1) Emotional } \\
\text { Capability }\end{array}$ & $\begin{array}{l}.558 \\
* * *\end{array}$ & $\begin{array}{l}.418 \\
* * *\end{array}$ & $\begin{array}{l}.30 \\
3 * * \\
*\end{array}$ & $\begin{array}{l}- \\
.24 \\
6^{* *}\end{array}$ & $\begin{array}{l}.0 \\
32\end{array}$ & -.061 & $\begin{array}{l}.190 \\
* *\end{array}$ & $\begin{array}{l}.239 \\
* * *\end{array}$ & $\begin{array}{l}- \\
* \\
*\end{array}$ & $\begin{array}{l}.05 \\
4\end{array}$ & .18 & .099 & $\begin{array}{l}.43 \\
2 * * \\
*\end{array}$ & $\begin{array}{l}.205 \\
* *\end{array}$ & $\begin{array}{l}.191 \\
* *\end{array}$ & $\begin{array}{l}.177 \\
* *\end{array}$ & $\begin{array}{l}.331 \\
* * *\end{array}$ \\
\hline $\begin{array}{l}\text { (2) Problem } \\
\text { Solving } \\
\text { Capability }\end{array}$ & -- & $\begin{array}{l}.595 \\
* * *\end{array}$ & $\begin{array}{l}.24 \\
7 * * \\
*\end{array}$ & $\begin{array}{l}- \\
.24 \\
5 * *\end{array}$ & $\begin{array}{l}.0 \\
00\end{array}$ & $\begin{array}{l}- \\
.215 \\
* *\end{array}$ & $\begin{array}{l}.323 \\
* * *\end{array}$ & $\begin{array}{l}.322 \\
* * *\end{array}$ & -.086 & $\begin{array}{l}.15 \\
9 * *\end{array}$ & $\begin{array}{l}.25 \\
7 * * \\
*\end{array}$ & $\begin{array}{l}.168 \\
* *\end{array}$ & $\begin{array}{l}.19 \\
1 * *\end{array}$ & $\begin{array}{l}.222 \\
* * *\end{array}$ & $\begin{array}{l}.185 \\
* *\end{array}$ & $\begin{array}{l}.285 \\
* * *\end{array}$ & $\begin{array}{l}.393 \\
* * *\end{array}$ \\
\hline (3) Motivation & -- & -- & $\begin{array}{l}.22 \\
5^{* *} \\
*\end{array}$ & $\begin{array}{l}- \\
.21 \\
7 * *\end{array}$ & $\begin{array}{l}- \\
.0 \\
93\end{array}$ & $\begin{array}{l}- \\
.160 \\
*\end{array}$ & .075 & $\begin{array}{l}.145 \\
*\end{array}$ & -.006 & $\begin{array}{l}.02 \\
5\end{array}$ & $\begin{array}{l}.12 \\
0^{*}\end{array}$ & -.019 & $\begin{array}{l}.11 \\
4\end{array}$ & .110 & .110 & .128 & $\begin{array}{l}.226 \\
* *\end{array}$ \\
\hline $\begin{array}{l}\text { (4) } \\
\text { Opportunity }\end{array}$ & -- & -- & -- & $\begin{array}{l}.00 \\
2\end{array}$ & $\begin{array}{l}- \\
.0 \\
29\end{array}$ & .050 & -.029 & .024 & -019 & $\begin{array}{l}- \\
.09 \\
7\end{array}$ & $\begin{array}{l}.00 \\
6\end{array}$ & -.081 & $\begin{array}{l}.13 \\
4^{*}\end{array}$ & .015 & -.010 & -.022 & .121 \\
\hline $\begin{array}{l}\text { (5) } \\
\text { Desmotivation }\end{array}$ & -- & -- & -- & -- & $\begin{array}{l}- \\
01 \\
3\end{array}$ & $\begin{array}{l}.245 \\
* *\end{array}$ & $\begin{array}{l}- \\
.319 \\
* * *\end{array}$ & $\begin{array}{l}- \\
.334 \\
* * *\end{array}$ & .085 & $\begin{array}{l}- \\
.15 \\
6^{*}\end{array}$ & $\begin{array}{l}- \\
.15 \\
9 *\end{array}$ & $\begin{array}{l}- \\
.260 \\
* * *\end{array}$ & $\begin{array}{l}- \\
.15 \\
1 *\end{array}$ & $\begin{array}{l}- \\
.381 \\
* * *\end{array}$ & $\begin{array}{l}- \\
.268 \\
* * *\end{array}$ & $\begin{array}{l}- \\
.373 \\
* * *\end{array}$ & $\begin{array}{l}- \\
.379 \\
* * *\end{array}$ \\
\hline (6) Instability & -- & -- & -- & -- & -- & $\begin{array}{l}.290 \\
* * *\end{array}$ & -.070 & -.089 & $\begin{array}{l}.210 \\
* * *\end{array}$ & $\begin{array}{l}- \\
.10 \\
7 \\
\end{array}$ & $\begin{array}{l}- \\
.16 \\
1 *\end{array}$ & -.079 & $\begin{array}{l}- \\
.12 \\
2 \\
\end{array}$ & $\begin{array}{l}- \\
.201 \\
* *\end{array}$ & -.016 & .039 & -113 \\
\hline (7) Isolation & -- & -- & -- & -- & -- & -- & $\begin{array}{l}- \\
.277 \\
* *\end{array}$ & $\begin{array}{l}- \\
.225 \\
* *\end{array}$ & $\begin{array}{l}.286 \\
* *\end{array}$ & $\begin{array}{l}- \\
.27 \\
6 * *\end{array}$ & $\begin{array}{l}- \\
.15 \\
9 *\end{array}$ & $\begin{array}{l}- \\
.221 \\
* *\end{array}$ & $\begin{array}{l}- \\
.05 \\
2\end{array}$ & $\begin{array}{l}- \\
.341 \\
* *\end{array}$ & $\begin{array}{l}- \\
.222 \\
* *\end{array}$ & $\begin{array}{l}- \\
.251 \\
* *\end{array}$ & $\begin{array}{l}- \\
.251 \\
* *\end{array}$ \\
\hline
\end{tabular}




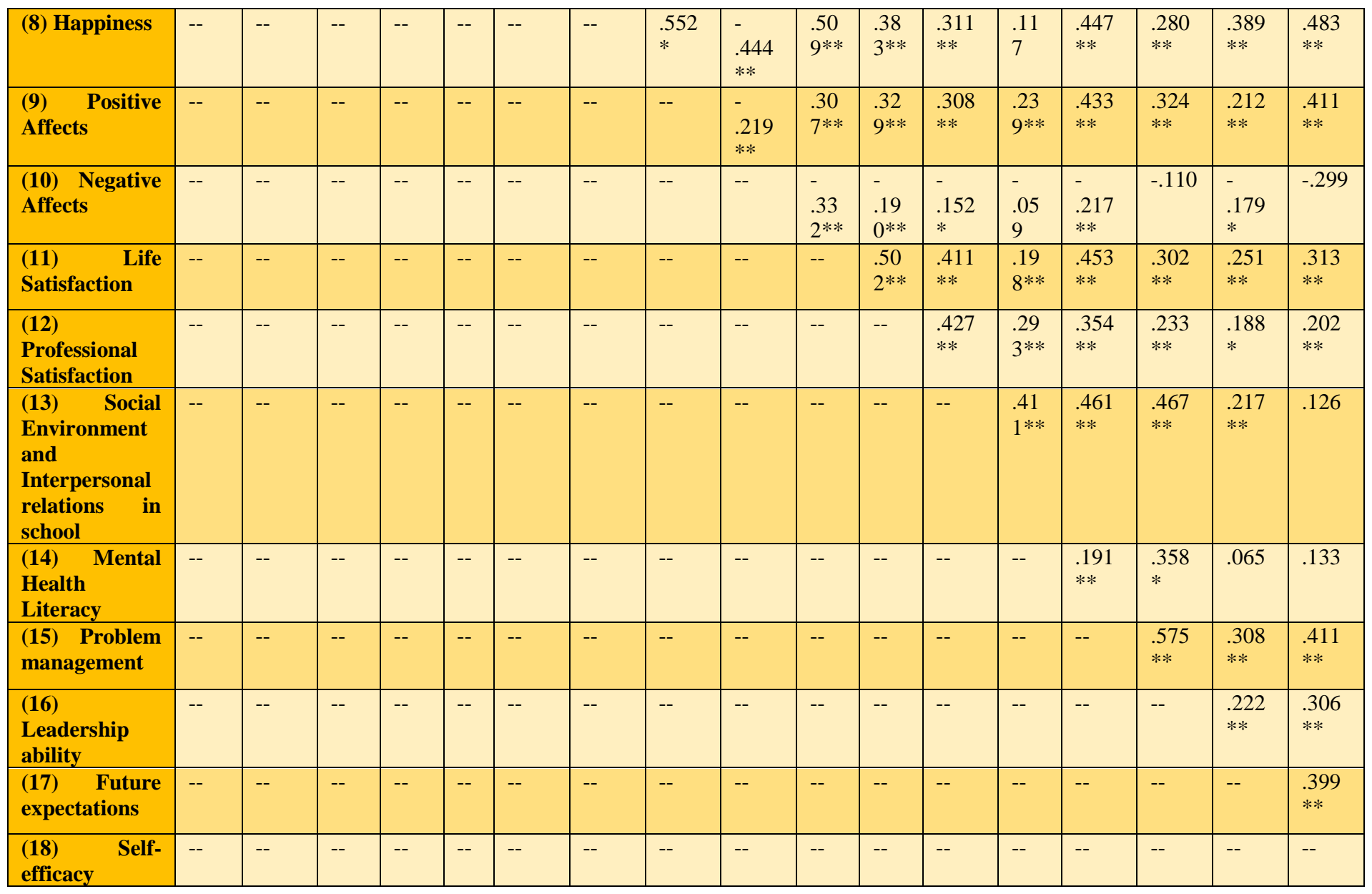

Table 3 - Correlations

Regarding the results observed in the t-Student test, it was found that after training there was an increase in most of the variables analyzed: Mental Health Knowledge and Attitudes Scale: emotional capability $(M$ $=19.6, S D=2.8)$, problem solving capability $(M=21.7, S D=2.3)$, motivation $(M=18, S D=1.9)$, opportunity $(M=15.2, S D=2.3)$; PANAS scale: positive affects $(M=37.4, S D=5.2)$; happiness $(M=21.7, S D=$ 3.6), professional satisfaction $(M=6.7, S D=1.6)$, social environment and interpersonal relations in school $(M=7.7, S D=1.3)$, self-efficacy $(M=$ $15.8, S D=1.9)$, mental health literacy $(M=7.3, S D=1.4)$, problem management $(M=7.7, S D=1.3)$, leadership ability $(M=7.3, S D=1.4)$ and life satisfaction $(M=7.5, S D=1.3)$. In the demotivation subscale (i.e., alienation scale) values decreased after training $(M=10.5, S D=2.2)$ (see table 4).

\begin{tabular}{|c|c|c|c|c|c|c|c|}
\hline & \multirow{3}{*}{ Emotional Capability } & \multicolumn{2}{|c|}{ Initial $(\mathrm{N}=276)$} & \multicolumn{4}{|c|}{ Final $(\mathrm{N}=276)$} \\
\hline \multirow{11}{*}{$\begin{array}{l}\text { Mental Health Knowledge } \\
\text { and Attitudes }\end{array}$} & & $\mathrm{M}$ & $\mathrm{DP}$ & $\mathrm{M}$ & SD & $\mathrm{t}$ & $p$ \\
\hline & & 18.6 & 2.7 & 19.6 & 2.8 & -7.183 & .000 \\
\hline & \multirow{3}{*}{$\begin{array}{l}\text { Problem } \\
\text { Capability }\end{array}$} & \multicolumn{2}{|c|}{ Initial $(\mathrm{N}=276)$} & \multicolumn{2}{|c|}{ Final $(\mathrm{N}=276)$} & & \\
\hline & & $\mathrm{M}$ & $\mathrm{DP}$ & $\mathrm{M}$ & SD & $\mathrm{t}$ & $p$ \\
\hline & & 21.2 & 2.3 & 21.7 & 2.3 & -4.549 & .000 \\
\hline & \multirow[t]{3}{*}{ Motivation } & \multicolumn{2}{|c|}{ Initial $(\mathrm{N}=276)$} & \multicolumn{2}{|c|}{ Final $(\mathrm{N}=276)$} & & \\
\hline & & $\mathrm{M}$ & $\mathrm{DP}$ & $\mathrm{M}$ & SD & $\mathrm{t}$ & $p$ \\
\hline & & 17.5 & 1.9 & 18 & 1.9 & -4.656 & .000 \\
\hline & \multirow[t]{3}{*}{ Opportunity } & \multicolumn{2}{|c|}{ Initial $(\mathrm{N}=276)$} & \multicolumn{2}{|c|}{ Final $(\mathrm{N}=276)$} & & \\
\hline & & $\mathrm{M}$ & $\mathrm{DP}$ & $\mathrm{M}$ & SD & $\mathrm{t}$ & $p$ \\
\hline & & 14.4 & 2.3 & 15.2 & 2.3 & -5.595 & .000 \\
\hline \multirow{2}{*}{ PANAS } & \multirow{2}{*}{ Positive Affects } & \multicolumn{2}{|c|}{ Initial $(\mathrm{N}=275)$} & \multicolumn{2}{|c|}{ Final $(\mathrm{N}=275)$} & & \\
\hline & & $\mathrm{M}$ & DP & $\mathrm{M}$ & SD & $\mathrm{t}$ & $p$ \\
\hline
\end{tabular}




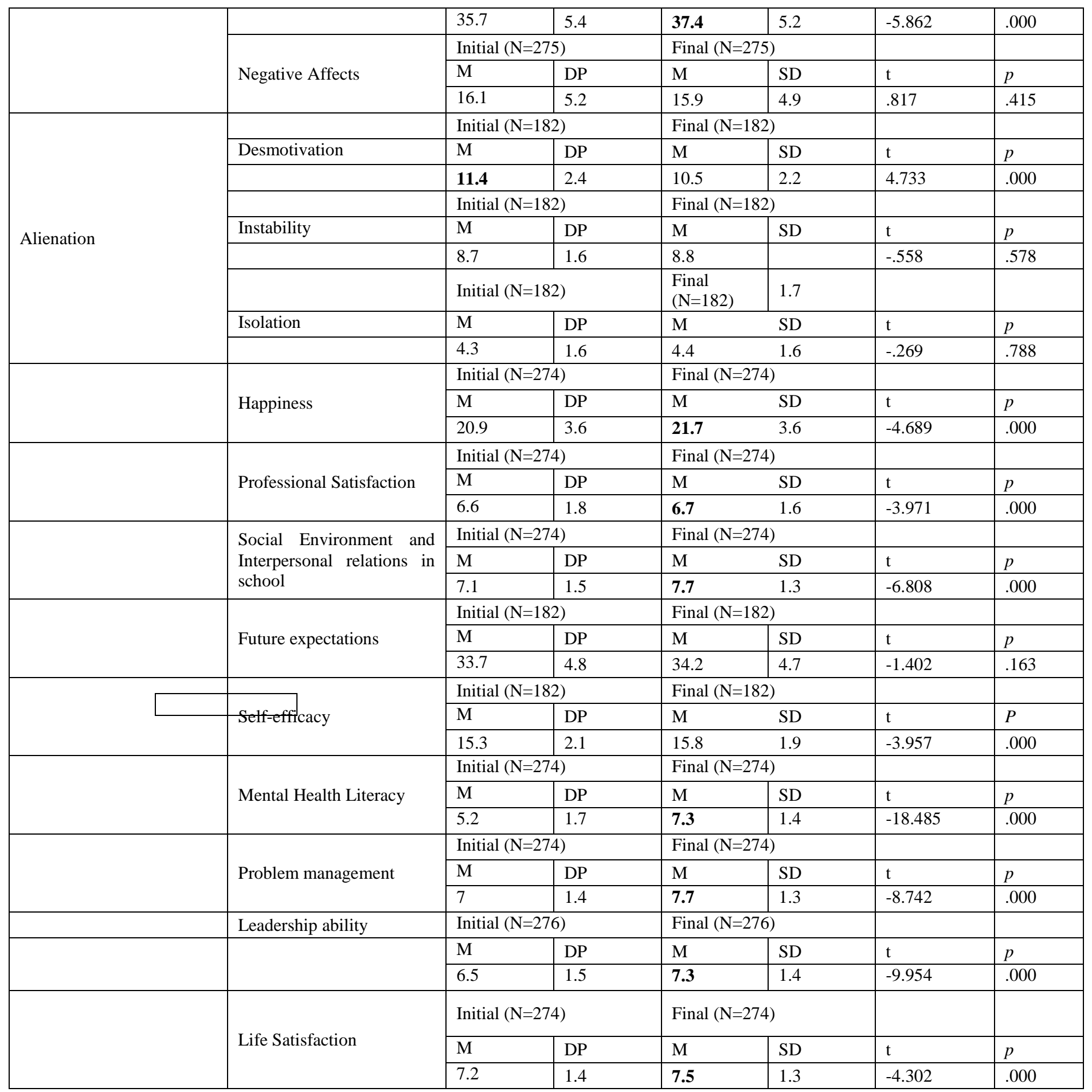

Table 4 -Pre and post evaluations comparisons using t-Student (paired samples)

To understand the predictive effect of the variables used in this study on Mental Health Knowledge and Attitudes Subscales, multiple linear regression analyses were conducted. In each of the models statistically significant variables were included in the correlations and a $\mathrm{T}$-test analysis with a significance level greater than $\mathrm{p} \leq .05$. In each model, the initial variable corresponding to the same final variable was controlled, so that its weight did not influence the values found in the model.

The regression equation for the model of the emotional capability (final) explained $29 \%$ of the variance $\left(R^{2}=.291\right)$. In this model, the explanation of the emotional capability (final) was obtained through the problem-solving capability (initial) $(\beta=.428, p=.000)$, opportunity (initial) $(\beta=.158, p=.025)$ and positive affects (initial) $(\beta=.222, p=.006)$. 
The model of the problem-solving capability (final) explained $20 \%$ of the variance $\left(R^{2}=.209\right)$. In this model, the explanation of the problem-solving capability (final) was obtained through the emotional capability (initial) $(\beta=.193, p=.032)$ and motivation (initial) $(\beta=.276, p=.000)$. The model of the motivation (final) explained $12 \%$ of the variance $\left(R^{2}=.121\right)$. In this model, the explanation of the motivation (final) was obtained through the problem-solving capability (initial) $(\beta=.321, p=.001)$, positive affects (initial) $(\beta=.208, p=.018)$ and leadership ability (initial) $(\beta=.214, p=.019)$. Finally, the model of the opportunity (final) explained $12 \%$ of the variance $\left(R^{2}=.127\right)$. In this model, the explanation of the opportunity (final) was obtained through the emotional capability (initial) $(\beta=.290$, $p=.004$ ) (see table 5).

\section{Discussion}

The mental health promotion in schools is a concern described in several studies $[3,10]$. Teachers have an essential role in converting the school environment into a well-being context and in promoting the mental health of young people. However, it seems that academic training is not enough to deal with mental health problems [4]. Thus, teacher training plays an essential role in supporting teachers in their functions.

The aim of this study was to analyse, in terms of mental health, the impact that teacher training had on their skills, knowledge and attitudes towards mental health. The main goal of "ES'COOL" is to promote adolescents' mental health through skills enhancement of school teachers and school staff. The program aims were the development of personal and social skills, while it includes the prevention of anxiety and depression symptoms and the promotion of resiliency, and self-regulation in adolescents. The ES'COOL training was implemented with teachers from primary and secondary schools (from 1 st to $12^{\text {th }}$ grade), kindergarten and special education teachers covering schools from all the regions of Portugal. Two evaluation moments were carried out: the initial evaluation - one week before the beginning of the training, and the final evaluation one week after the end of the training.

\begin{tabular}{|c|c|c|c|c|c|c|}
\hline \multirow{18}{*}{$\begin{array}{l}\text { Emotional Capability } \\
\text { (Final)* } \\
\text { (*Model weighted by } \\
\text { the emotional } \\
\text { Capability -Initial) }\end{array}$} & Variable included & $\beta$ & $\bar{t}$ & $p$ & $\boldsymbol{R}_{a}^{2}$ & $F(\text { model fit })^{*}$ \\
\hline & $\begin{array}{l}\begin{array}{l}\text { Problem Solving Capability } \\
\text { (Initial) }\end{array} \\
\end{array}$ & .428 & 4.629 & .000 & \multirow{17}{*}{.291} & \multirow{17}{*}{5.372} \\
\hline & Motivation (Initial) & -.063 & -.755 & .451 & & \\
\hline & Opportunity (Initial) & .158 & 2.265 & .025 & & \\
\hline & Desmotivation (Initial) & -.014 & -.186 & .852 & & \\
\hline & Instability (Initial) & -.080 & -1.122 & .264 & & \\
\hline & Isolation (Initial) & .052 & .703 & .483 & & \\
\hline & Positive Affects (Initial) & .222 & 2.791 & .006 & & \\
\hline & Negative Affects (Initial) & -.096 & -1.262 & .209 & & \\
\hline & Happiness (Initial) & -.172 & -1.785 & .076 & & \\
\hline & Life Satisfaction (Initial) & -.133 & -1.485 & .139 & & \\
\hline & $\begin{array}{ll}\begin{array}{l}\text { Professional } \\
\text { (Initial) }\end{array} & \text { Satisfaction } \\
\end{array}$ & .096 & 1.173 & .243 & & \\
\hline & $\begin{array}{lrr}\text { Social Environment } & \text { and } \\
\text { Interpersonal relations } & \text { in } \\
\text { school (Initial) } & & \\
\end{array}$ & -.055 & -.696 & .487 & & \\
\hline & $\begin{array}{lll}\begin{array}{l}\text { Mental } \\
\text { (Initial) }\end{array} & \text { Health } & \text { Literacy } \\
\end{array}$ & .049 & .653 & .515 & & \\
\hline & Problem management (Initial) & .090 & .952 & .343 & & \\
\hline & Leadership ability (Initial) & .090 & 1.107 & .270 & & \\
\hline & Future expectations (Initial) & .090 & 1.212 & .227 & & \\
\hline & Self-efficacy (Initial) & -.135 & -1.624 & .106 & & \\
\hline \multirow{15}{*}{$\begin{array}{l}\text { Problem Solving } \\
\text { Capability (Final)* } \\
\text { (* Model weighted by } \\
\text { the Problem Solving } \\
\text { Capability -Initial) }\end{array}$} & Variable included & $\beta$ & $\bar{t}$ & $\bar{p}$ & $\boldsymbol{R}_{a}^{2}$ & $F(\text { model fit })^{*}$ \\
\hline & Emotional Capability (Initial) & .193 & 2.161 & .032 & \multirow{14}{*}{.209} & \multirow{14}{*}{3.821} \\
\hline & Motivation (Initial) & .276 & 3.612 & .000 & & \\
\hline & Opportunity (Initial) & .073 & .997 & .320 & & \\
\hline & Demotivation (Initial) & .012 & .151 & .880 & & \\
\hline & Instability (Initial) & -.023 & -.307 & .759 & & \\
\hline & Isolation (Initial) & -.048 & -.620 & .536 & & \\
\hline & Positive Affects (Initial) & .113 & 1.354 & .178 & & \\
\hline & Negative Affects (Initial) & .035 & .431 & 667 & & \\
\hline & Happiness (Initial) & .090 & .910 & .364 & & \\
\hline & Life Satisfaction (Initial) & -.081 & -.857 & .393 & & \\
\hline & $\begin{array}{ll}\begin{array}{l}\text { Professional } \\
\text { (Initial) }\end{array} & \text { Satisfaction } \\
\end{array}$ & .055 & .646 & .519 & & \\
\hline & $\begin{array}{lrr}\text { Social Environment } & \text { and } \\
\text { Interpersonal relations } & \text { in } \\
\text { school (Initial) } & & \end{array}$ & .096 & 1.140 & .256 & & \\
\hline & $\begin{array}{lll}\begin{array}{l}\text { Mental } \\
\text { (Initial) }\end{array} & \text { Health } & \text { Literacy } \\
\end{array}$ & -.079 & -.926 & .356 & & \\
\hline & Problem management (Initial) & -.034 & -.338 & .738 & & \\
\hline
\end{tabular}




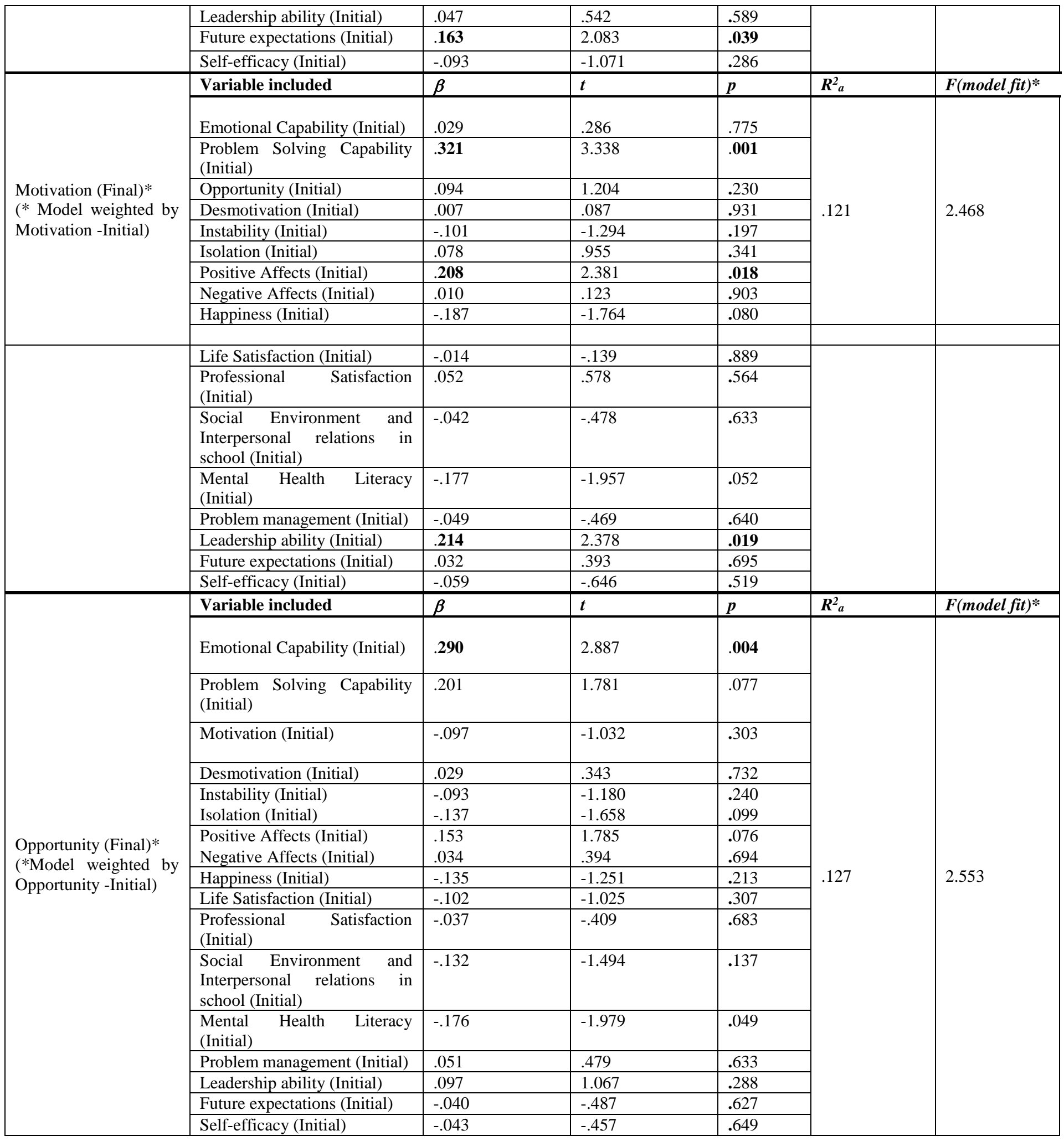

* Model weighted by Opportunity (Initial)

Table 5 - Mental Health Knowledge and Attitudes - Subscales Predictors - Linear Regression (Enter Method)

The findings revealed that teachers improved most of the assessed skills and knowledge after training. The variables that had the greatest impact on improving competences after training were problemsolving skills, motivation and leadership skills. These results are in line 
with studies that describe teacher training or educational community interventions as essential for the mental health promotion in the school context $[7,9 ; 10]$. According to the literature $[3,7]$, having more skills and better subjective well-being are essential factors in dealing adequately with students' problems.

These results prove to be crucial as they demonstrate the importance and need to develop more teacher training. It was also important to analyse which skills and characteristics had the most influence on the final results. Authors, such as Severiens, [8], tried to understand the most important skills that a good teacher should have, and found: interpersonal competence, pedagogical competence, content competence, competence in cooperation with parents and other professionals. In this study, some competences that were present at the beginning of the training not only improved, but also influenced the positive results obtained at the end of the training. Identifying these competences consents their reinforcement, going beyond the competences and knowledge in mental health, the teachers' own wellbeing, which is also considered another essential factor for the students' well-being [15].

Subsequently, the continuity of the work carried out on mental health promotion in the school context is fundamental, especially the work with teachers, in order to overcome the gaps in this area. It is also essential to understand the factors that influence the teacher's well-being in order to keep them motivated and able to help young people with their problems.

\section{Key messages}

Teachers and school staff refer difficulties dealing with student's well-being and mental health issues, matters of upmost importance for students personal and academic well-being and optimised performance.

A Training program (ESCool) aiming at promoting teachers' and school staff knowledge and the capacity to screening mental health issues and to creating environmental school conditions that might promote a healthy ecosystem had promising positive results during a quasi-experimental trial.

ES'Cool greatest impact was upon competences such as problem-solving skills, motivation and leadership skills.

\section{References}

1. Allen, K. A., and McKenzie, V. L. (2015). Adolescent Mental Health in an Australian Context and Future Interventions. International Journal of Mental Health, 44(1-2), 80-93. doi.org/10.1080/00207411.2015.1009780

2. WHO (2013). Mental health action plan 2013-2020. Geneva: WHO
3. Akyol, M. A., and Akdemir, E. (2019). Comparison of Emotional Intelligence Levels and Problem Solving Skills of Prospective Teachers According to Different Variables. World Journal of Education, 9(3), 131-141.

4. Armstrong, D., Price, D., and Crowley, T. (2015). Thinking it through: a study of how pre-service teachers respond to children who present with possible mental health difficulties. Emotional and Behavioural Difficulties, 20(4), 381-381 - 397. doi:10.1080/13632752.2015.1019248

5. Askell-Williams, H., and Cefai, C. (2014). Australian and Maltese teachers' perspectives about their capabilities for mental health promotion in school settings. Teaching and Teacher Education, 40, 61. doi:10.1016/j.tate.2014.02.003

6. Ekornes, S. (2017). Teacher Stress Related to Student Mental Health Promotion: The Match between Perceived Demands and Competence to Help Students with Mental Health Problems. Scandinavian Journal of Educational Research, 61(3), 333.

7. Mundia, L. (2013). Relationship between mental health and teaching. International Journal of Mental Health 42(2-3), 73-98.

8. Severiens, S., Wolff, R., and Van Herpen, S. (2014). Teaching for diversity: A literature overview and an analysis of the curriculum of a teacher training college. European Journal of Teacher Education, 37(3), 295-311.

9. Shah, H., and Kumar, D. (2012). Sensitizing the teachers towards school mental health issues: an Indian experience. Community Ment Health J, 48(4), 522-526. doi:10.1007/s10597-011-9437-2

10. Tomé, G., Almeida, A., Ramiro, L., Gaspar, T., and Matos, M.G. (2020). Intervention in Schools promoting mental health and wellbeing: a systematic review. Global Journal of Community Psychology Practice (submitted)

11. Matos, M., Simões, C., Camacho, I., Reis, M. (2015). A Saúde dos Adolescentes Portugueses em tempos de recessão. HBSC 2014. Lisboa: CMDT/ DGS/ FMH/

12. Lyubomirsky, S., and Lepper, H. S. (1999). A measure of subjective happiness: Preliminary reliability and construct validation. Social Indicators Research, 46(2), 137-155.

13. Tomé, G., Matos, M.G., Camacho, I., Gomes, P., Reis, M., et al. (2018). Mental Health Promotion in School Context - Validation of the ES'COOL Scale for Teachers. Journal of Psychiatry and Behavioral Sciences, 2:1009.

14. Watson, D., Clark, L. A., and Tellegen, A. (1988). Development and validation of brief measures of positive and negative affect: the PANAS scales. Journal of Personality and Social Psychology, 54(6), 1063-1070.

15. Cruz, J. (2016). Estilos de Liderança dos Professores e Comportamentos de Risco de Alunos Adolescentes. Tese elaborada com vista à obtenção do Grau de Doutor em Ciências da Educação na Especialidade de Educação para a Saúde. Faculdade de Motricidade Humana. 
(c) ()

This work is licensed under Creative

Commons Attribution 4.0 License

To Submit Your Article Click Here: Submit Article

DOI: $10.31579 / 2637-8892 / 101$
Ready to submit your research? Choose Auctores and benefit from:

* fast, convenient online submission

* rigorous peer review by experienced research in your field

* rapid publication on acceptance

* authors retain copyrights

* unique DOI for all articles

* immediate, unrestricted online access

At Auctores, research is always in progress.

Learn more www.auctoresonline.org/journals/psychology-andmental-health-care 